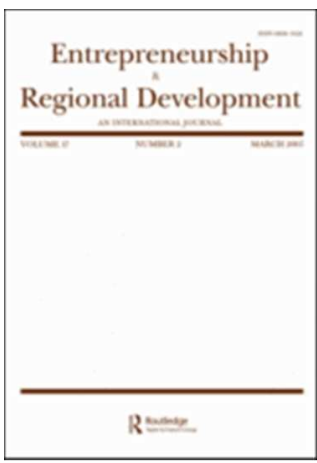

The role of Technological Business Incubators in supporting business innovation in China: a case of regional adaptability?

\begin{tabular}{|r|l|}
\hline Journal: & Entrepreneurship \& Regional Development \\
\hline Manuscript ID & TEPN-2017-0134 \\
\hline Manuscript Type: & Original Paper \\
\hline Keywords: & $\begin{array}{l}\text { Incubator support, venture capital, scientific resources, new ventures, } \\
\text { innovations }\end{array}$ \\
\hline \multicolumn{2}{|l}{} \\
\hline
\end{tabular}

SCHOLARONE ${ }^{m}$

Manuscripts 


\title{
The role of Technological Business Incubators in supporting business innovation in China: a case of regional adaptability?
}

\begin{abstract}
This paper examines the extent to which both the support services of technological business incubators (TBIs) and exogenous local factors facilitate the innovation activity of incubated new ventures. Using data on all 215 surviving Chinese incubators and their incubated firms from government surveys conducted over five consecutive years from 2009 until 2013, combined with information from nine case studies, we examine the effects of four incubator services on three levels of innovation in incubated firms, whilst also taking account of key exogenous factors. Technical service support from an incubator was found to have had a positive influence on all levels of innovation activity across all regions whilst financial support had a positive effect on the making of more advanced innovations. The availability of venture capital had a significant impact on making lower order innovations whereas the availability of scientific knowledge resources influenced more advanced innovation activity. Whereas TBI support services in the more developed Eastern region are mainly concerned with leveraging external resources, those in the less developed Central and Western regions are more concerned with compensating for the lack of external resources to support innovation.
\end{abstract}

Key words: Incubator support, venture capital, scientific resources, new ventures, innovations 


\section{Introduction}

Since the 1980s, Technological Business Incubators (TBIs) have been considered by governments in both developed and developing economies to be an important mechanism for stimulating technology-based entrepreneurial activity (Phan et al., 2005). They have become an accepted catalytic instrument of economic development, providing a range of business resources and services to nurture and support the growth of new technology-based ventures (NBIA, 2007). Although there has been considerable research interest in various aspects of the development of TBIs in the USA and Europe (e.g. Mian, 1996; Phan et al., 2005; Mian et al., 2016), there have been fewer studies of their contribution to economic development in transition economies such as China given the rapid growth in the numbers of TBIs over the last quarter century (Dutt et al, 2016; Smith \& Zhang, 2012). We also know relatively little about the role TBIs are playing in China in supporting innovation in diverse spatial contexts, particularly the differences between more and less developed regions. As recognised by Kuratko \& LaFollette (1987), business incubators are likely to make specific regional adaptations in order to fit spatially diverse needs and conditions. Thus their aims, organisational structure and provision of services are likely to adapt to local circumstances and the challenges of creating successful technology-based businesses. Moreover, the availability of other local resources such as human and financial capital is likely to influence to some extent the outcomes from TBIs (Theodorakopoulos et al 2014; Dee et al, 2011).

China is playing an increasingly important role in the global knowledge economy through developing a new generation of TBIs to facilitate business innovation (OECD, 2007). It therefore presents a fascinating context in which to study the possible influences of TBI support services on the innovation activity of new technology-based enterprises. Furthermore, China is characterised by large geographical disparities in terms of economic development that are becoming greater as the economy grows. Thus we might expect that the kind of support that TBIs give to the development and commercialisation of innovations in incubatees (i.e. incubated firms) to vary according to the economic health of a TBI's host region (Folta et al., 2006; Fritsch and Slavtchev, 2011). TBIs located in regions with a more entrepreneurial culture and support infrastructure are likely to have an advantage over those in regions lacking in these respects. This paper covers all three of China's mega geographical regions classified according to their level of wealth and economic development, consisting of 
the more economically developed and wealthy Eastern coastal provinces, the relatively poor Central provinces, and the poorest Western provinces. The role that TBIs are playing in these different regional contexts is therefore of particular interest.

Our research focuses on the extent to which there is a relationship between the investment made by TBIs in various support services and the level of innovation activity within incubated technology-based ventures. We are interested in whether the nature of this relationship differs throughout China, comparing the more prosperous Eastern region with the less prosperous Central and Western regions. This exploratory study draws upon a unique survey dataset covering all the TBIs and incubated new ventures in China over five consecutive years from 2009 until 2013 in order to examine the influence of four types of support service provided by TBIs on the levels of innovation undertaken by incubatees. Other secondary data is also used to examine the possible influences of certain key exogenous factors. Further insights concerning the nature of the support services and how these relate to the aims, origins, and local context of TBIs are gained from nine case studies that we examined in 2015 and 2016.

This paper makes four distinctive contributions to the literature on TBIs. First, it extends our knowledge of the role being played by TBIs in China, a country that until now has been relatively unexplored in these terms. Second, whilst much previous research on TBIs in the West has focused on the performance of incubatees in terms of their early growth, graduation and subsequent survival, our research enhances understanding of the effects of TBI support services on three levels of innovation undertaken by incubatees. Third, we also consider the availability of other key external resources which may interact with the support services and resources provided by the TBIs themselves to facilitate innovation within incubatees. And fourth, by undertaking the modelling separately for China's three mega regions, the research examines whether there is evidence to support the notion that TBIs make regional adaptations, depending on the availability of other local resources.

The rest of the paper is organised as follows. First, we outline the origins and development of Chinese TBIs before reviewing relevant literature from both advanced and emerging economy contexts on the contribution of incubators to innovation and economic development. This leads to three hypotheses concerning possible influences on levels of innovation found within Chinese TBIs. The dataset covering all TBIs and incubated new ventures in China is then described together with our methodology. In presenting our 
findings, we first discuss the results of the statistical modelling before considering some more qualitative insights gained from interviews with TBI managers and entrepreneurs in the nine case study TBIs. Finally, we consider the wider implications of the findings and further research opportunities.

\section{The growth of TBIs in China}

TBIs were initially designed by the Ministry of Science and Technology (MOST) in China to help commercialise scientific technologies by providing mainly physical buildings, facilities and financial incentives (e.g. preferential tax policy and grants) to selected technology-based start-up firms originally founded and operated by research scientists and more recently by university graduates being encouraged to establish high-tech ventures. Early incubators were located near to leading universities and research institutes with abundant scientific resources (Hong, 2008). The first incubator, Wuhan Donghu Pioneers Centre (WDPC), was formally established in 1987 and located in the Eastlake new technology development zone close to Wuhan University, a leading university specialising in science and engineering in the Central region. Although not part of a government programme initially, WDPC gained approval from local government and then became part of the Chinese government's Torch Programme. The success of WDPC became a model for other major cities mainly from the more developed Eastern region. By 1997, 80 incubators housed 2,670 firms with 45,600 employees (China Torch Statistics Yearbook, 2000), these being centred on eight major cities. During the early stages of their evolution, incubators were entirely funded by the MOST and the Department of Science and Technology at a provincial level and managed by government officials. State ownership and management led to the early incubators being primarily focused on the number of incubated firms established over a given period of time, reflecting the performance targets of government officials. In other words, the focus of the first generation of TBIs was primarily on new business formation with the ultimate goal of creating jobs and contributing to regional economic development rather than necessarily on supporting those business ventures that had the potential to produce advanced innovations and to become major market players. Consequently, the emphasis tended to be placed on selecting those ventures that could be established quickly and capable of graduating within a year or two of entering the incubator.

From 2000 onwards, the Chinese government encouraged combining public resources from the MOST and local science and technology committees with resources from other public and 
private sources (notably large state-owned enterprises, stock market listed companies, foreign investors, universities, and private investors) to fund the continued growth of TBIs. Incubator ownership therefore changed from being solely state-owned to being more diverse, particularly in the major cities, although incubators located in the less developed regions were still more likely to be state funded and operated by government officials. In recent years governments at national, provincial, and local levels have provided more public resources and incentives to both established and new TBIs, with the declared aim in China's $12^{\text {th }}$ five year plan (2011-2015) of helping new ventures develop breakthrough innovations capable of catching up or surpassing their main competitors in the international market. As a result, to qualify for state funding the latest generation of TBIs are having to focus more on supporting the innovation process in incubatees, ranging from innovation thinking through making prototypes to market testing and commercialisation. Moreover, the criteria used to assess senior managers of government-owned TBIs now emphasise advanced and breakthrough innovations and the creation of firms capable of becoming market leaders after graduation, even if that takes several years to achieve. Thus seeking out new and young ventures capable of undertaking advanced innovations is more important to the latest generation of stateowned TBIs than the earlier generation ones. Indeed, they are likely to be keener on allocating their resources to tailored support services to realise the innovation potential of incubatees than privately owned TBIs. A consequence of the different kinds of ownership of the latest generation of Chinese TBIs is that there is now greater diversity in the types of ventures that are selected to enter incubators than previously.

Table 1 shows the marked disparities in the geographical distribution of TBIs and incubated firms across China's three mega regions. It also reveals the continued rapid growth and development of TBIs and incubatees in China as a whole, with the number of TBIs rising from 228 in 2009 to 378 in 2012 (giving an average annual growth of 21.9 per cent) and incubatees increasing from 27,920 in 2009 to 39,635 in 2012 (giving an average annual growth of 25 per cent). Moreover, the growth of both TBIs and incubatees has been significantly faster in the Eastern region than in the other two regions, leading to their distribution becoming even more geographically concentrated in recent years, with 68.0 per cent of incubators and 63.0 per cent of incubatees being located in the Eastern region by 2012.

Table 1 about here 


\section{Literature Context}

\section{Defining and measuring innovation}

Innovation is an elusive concept which has been interpreted in different ways by different authors. There has been an increasing tendency to widen the definition of innovation to include the transfer or adoption of ideas and methods which are 'new to the firm' as well as those which are 'new to an industry' or 'new to a market'. It is not coincidental that this wider view of innovation has become more accepted as the economic importance of new and small enterprises has grown (Rothwell and Zegveld, 1982; North and Smallbone, 2000; Mansury and Love, 2008; Varis and Littunen, 2010). Therefore distinctions are often made between advanced/radical and incremental innovations and also between lead and follower technology businesses. A lead technology business requires a larger amount of investment and higher level of risk taking, with the prospect of making a higher return, compared to a follower technology business that re-invents or modifies the original innovation (Perez-Luno et al., 2011).

It can be assumed that the support services and resources required by incubated ventures from a TBI vary according to the nature and level of innovation activity that they undertake and the stage of the innovation process that they have reached. Similarly, this can also be assumed to affect the demand for resources and expertise from beyond the TBI itself. Thus, it seems reasonable to expect that those incubatees engaged in more radical and advanced innovation activity will require more specialised facilities and expert assistance than those making incremental, modifying innovations requiring more generic facilities and expertise.

\section{TBI services and innovation}

The earliest studies of TBIs assessed the benefits of various support services offered by incubators, including shared office services, business assistance, capital availability, business networks, and rent breaks (Allen and Rehman, 1985; Smilor, 1987; Hisrich and Smilor, 1988). Interestingly, though, it was noted that some of the earlier business incubators in Europe relaxed their entry criteria in an effort to fill up space and generate rental income, rather than being totally dedicated to the creation of new technology-based businesses (Hackett and Dilts, 2004; Bruneel et al, 2012). Later literature focused on the university links and management practices of incubators as well as their impact on the growth performance of 
technology-based firms (Clarysee et al., 2005; Phan et al, 2005; Grimaldi and Grandi, 2005; NBIA, 2007; Ratinho and Henriques, 2010; Grimaldi et al., 2011). It has been shown that the support services provided by TBIs evolved over time from offering physical space and a shared infrastructure to facilitating access to external knowledge networks (Mian, 1996; Etzkowitz et al., 2005; Bergek and Norrman, 2008; Salvador, 2011), sometimes expressed as a shift of emphasis from focusing on tangible to less tangible elements (Theodorakopoulos et al., 2014). Recent research has shown not only that the latest generation of European business incubators is more focused on new technology-based firms than were previous generations, but also that greater emphasis is now placed on building networks such as those with business angels, venture capitalists and other business partners (Bollingtoft and Ulhoi, 2005; Aerts et al., 2007; Bruneel et al., 2012; Pauwels et al., 2016). In these various ways TBIs provide a nurturing environment for the creation and early development of innovative business ventures through enhancing the availability of key resources that technology entrepreneurs may have difficulty in sourcing on their own from elsewhere (Colombo and Delmastro, 2002; Lee and Osteryoung, 2004; Markman et al., 2005; Rothaermel and Thursby, 2005; Lockett and Wright, 2005; McAdam and McAdam, 2008). In other words, TBIs create an internal context and leverage external resources to exploit the ideas and innovations of entrepreneurs that are assessed to have commercial potential, thereby contributing to the formation and early development of new technology-based businesses. This is likely to involve refining ideas and innovations through a process of co-production between the staff of the incubator and the incubatee (Rice, 2002).

The literature on TBIs in developed economies primarily examines those incubators linked to universities (Lofsten and Lindelof, 2002; Markman et al., 2005; Rothaermel and Thursby, 2005; Amezcua et al 2013). These studies suggest that incubatees are most likely to be created by academic entrepreneurs who have already developed their innovations within universities or research institutes before being selected to enter an incubator (Mian 1996; Dee et al, 2011). Various university-related inputs such as laboratories, equipment, student employees, reputation and image can add major value to new ventures within the linked incubator (Mian, 1996) and have been shown to reduce the likelihood of firm failure (Ferguson and Olofsson, 2004; Rothaermel and Thursby, 2005). However, as these academic and technology entrepreneurs often lack the skills, knowledge and experience required to exploit a business opportunity (Franklin et al., 2001, Xiao and Ramsden, 2016), they are generally in need of business advice and networking support including help with accessing 
finance to help launch their business (Fritsch and Mueller, 2004; Janhiainen, 2008; Hendry et al., 2000; Zhang et al., 2011). Studies of university-based incubators point to the importance of being able to access entrepreneurial skills and knowledge as well as links to business networks, helping incubatees with commercialising a technological development and evaluating its commercial prospects (Meyer, 2003). However, this may not always be the case, particularly for TBIs that are not affiliated with a university (Wright et al., 2008; Colombo et al., 2012), Also, in transition economies like China where innovation systems are less well developed, there are likely to be fewer opportunities for interactive learning (Dutt et al, 2016; Xiao and North, 2016). Therefore in these contexts TBIs may need to incubate new/young ventures that are at the early stages of the innovation process and require the technical and laboratory support needed for testing their ideas and developing prototypes.

The literature acknowledges the importance of the provision of specific types of support by TBIs to remove and reduce the constraints that new ventures have in progressing and commercialising innovations (Perez-luno et al., 2011; Berry et al., 2006). These include difficulties in accessing affordable scientific resources, financial constraints, a lack of entrepreneurial skills, and insufficient contacts with potential clients and suppliers (Chan and Lau, 2005). The support services needed to tackle these problems can therefore be categorised into technical support, financial support, entrepreneurial assistance, and professional services. In deciding on the nature of these support services TBI managers will be taking account of various regional and local conditions, including the strength of the venture capital market, innovation systems, and the industrial structure. For instance, by providing technical support services themselves, TBIs aim to remove or reduce the constraints that incubatees experience in accessing scientific knowledge and resources that are affordable to them (Markman et al., 2005; Rothaermel and Thursby, 2005; Amezcua et al 2013). In developed countries, this is likely to be achieved through enabling incubatees to network with scientists from universities and research institutes (Henson et al., 2000; Lee and Osteryoung, 2004; McCann and Folta, 2011; Fritsch and Slavtchev, 2011). Whereas researchers who have begun examining TBIs in emerging-market countries identify that the direct provision of shared laboratory facilities and technical equipment by TBIs themselves is more likely (Dutt et al., 2016; Xiao and North, 2016).

Previous research has acknowledged the importance of the provision of direct financial support (e.g. research grants) by TBIs to creating and growing new innovative ventures (Perez-luno et al., 2011; Berry et al., 2006). In some countries, notably Israel, the 
management of TBIs (which are mostly privately owned) is able to provide equity capital for their incubatees, seeing them as an investment that needs to be nurtured for the long run rather than as shorter term 'real-estate' assets (Rubin et al, 2015).

It has been well documented that TBIs provide professional services to incubated technologybased firms in assisting their survival and early development in developed countries (Aerts et al, 2007; Bruneel et al., 2012). These services may include advice on licensing, legal protection and patent searching, although they are also likely to embrace networking between firms within an incubator (Adkins 2002, Lalkaka and Bishop, 1996; Thierstein and Willhelm, 2001) and with potential suppliers, customers, venture capitalists and business angels. In contrast, TBIs in emerging-market countries play a more direct role in assisting new and young technology-based ventures adapt to the country's institutional environment and in addressing institutional failures (Dutt et al., 2016; Liu and White, 2001). For instance, the role played by Chinese TBIs reflects the country's institutional environment, with new business ventures needing to be guided through the complex landscape of laws, procedures, regulations, government funding sources and property rights (Ahlstrom \& Ding, 2014).

\section{Exogenous resources}

The influence of a TBI on the innovations of incubatees may also vary depending upon the provision of key resources from other local organisations (e.g. specialised skills and knowledge, subcontractor and supplier systems, the presence of customers and users, and sources of finance) (Dutt et al., 2016; Cooke, 2001; Todtling and Kaufmann, 2001). The literature on TBIs has acknowledged the importance of obtaining and/or linking to exogenous resources for the growth of technology-based small firms (Lee et al., 2001; Siegel et al., 2007). Thus the ability of incubator management to bring about change in their incubatees is likely to vary, depending on their ability to access other local resources (Fernández Fernández et al, 2015). For example, in a more developed region, investments by an incubator's management may make an incubatee more attractive to other finance providers whereas in a less developed region, the provision of incubator finance may compensate for a lack of alternative sources of finance. In other words, the preconditions for innovation activity amongst new technology-based enterprises are associated with the interrelation between incubator support services and the availability of key local resources such as venture capital and scientific knowledge resources. Studies looking specifically at knowledge transfer and academic entrepreneurship found that the availability of 'star scientists' and venture 
capital in an incubator's regional economy were positively associated with the performance of start-up and spin-off firms (Siegel et al., 2004; Powers and McDougall, 2005). Close ties between entrepreneurs and private investors generally lead to more sources of finance and entrepreneurial expertise being invested in firms (Shane and Cable, 2002), thereby improving their chances of survival and growth (Wright et al., 2004).

In transition economies such as China, informal investors play an increasingly important role in providing equity finance to technology-based firms and have been found to prefer investing in incremental and modifying innovations rather than in the advanced research needed for more radical innovations (Xiao and North, 2012). Informal investors are also less likely than venture capital investors in a Western context to make a 'hands-on' contribution to an investee firm in terms of contributing their knowledge, skills, expertise, and contacts (Xiao and Ritchie, 2009). Informal investors typically rely on their social and business networks to assess an investment opportunity and make an investment decision (Ahlstrom and Bruton, 2010). Spatial proximity to the wealth and capital funds within a region therefore places incubated technology-based firms in a better position to network with potential investors, giving them greater access to risk capital. Arguably, therefore, new business ventures locating in more developed regions have the advantage of easier access to private venture capital and equity finance than their counterparts in less developed regions. Recent research has drawn attention to the uneven spatial concentration of VC investment activity in China, including the spatial distribution of public VC schemes (Li, 2015). This suggests that TBIs throughout China will differ in the extent to which they need to address market gaps in the availability of finance to fund new innovative business ventures.

The stock of leading scientists and research facilities in a region is seen to be associated with a region's attractiveness to technology entrepreneurs (Keeble, 1997; Tellis et al., 2009; Smith and Bagchi-Sen, 2012). A study focusing on the effective transfer of scientific knowledge from academics to firms in the US found that one-on-one interaction with academic scientists enabled new firms to refine innovative ideas and arrange to work with academics (Siegel et al., 2003). Proximity to universities helps firms gain access to scientific knowledge resources (i.e. academic scientists, research equipment), positively contributing to innovation inputs and outputs (Fritsch and Slavtchev, 2011). For example, a study looking into publicly traded biotechnology companies in the US reported that companies interacting with a university had lower R\&D expenditure while having a higher level of innovation output (George et al., 2002). Following this line of argument, the larger pool of scientific knowledge resources 
within core regions (Hensen, 1992; Storper, 1995) is likely to improve the ability of firms to reduce the costs of conducting innovations by utilising laboratory equipment and engaging with academic scientists. This leads us to expect that the innovation activity of incubatees will vary depending on the provision of nearby scientific knowledge resources i.e. from the city or municipality in which a TBI is located.

The literature reviewed above suggests that the various support services provided by a TBI will enhance the ability of incubatees to progress and commercialise innovations but the extent to which this can be achieved will also depend on other factors associated with the specific geographic context. In some contexts the emphasis of TBI management will be on enabling their incubatees to access exogenous resources, whereas in other contexts they are more likely to be concerned with compensating for the lack of such resources. Given this literature context, this paper aims to examine various influences on the levels of innovation undertaken by new business ventures within TBIs in China, focusing particularly on: (i) the type and scale of services provided by incubators themselves; and (ii) selected exogenous factors, specifically the availability of venture capital and scientific knowledge resources. As such we propose the following three hypotheses:

H1. The level of innovation undertaken by incubated firms will be positively associated with the type and scale of service support that the TBI provides i.e. lower level, incremental innovations will be associated with more generic support services whereas higher level, advanced innovations will be associated with more tailored services.

H2. The level of innovation undertaken by new business ventures within a TBI will be positively associated with (a) the availability of private venture capital and (b) the availability of scientific knowledge resources within the host city of the TBI i.e. higher level, advanced innovations will be associated with greater availability of both venture capital and knowledge resources than lower level, incremental innovations.

In addition, because of the marked regional economic disparities within China and therefore the different interactions between the support services of incubators and exogenous resources, we propose that:

H3. The support services provided by TBIs will have a more significant and direct impact on the innovation activities of incubated firms in the less developed regions (i.e. 
Central and Western regions) where the supply of exogenous resources (i.e. venture capital and knowledge resources) is more limited than is the case in the more developed region (i.e. Eastern region).

\section{Methodology}

In this section we first describe the various operational measures that we used to test the above hypotheses before detailing our data sources and modelling procedures.

\section{Measures of innovation}

To avoid the limitations of using a single measure of innovation, this study employs three different indicators which are used by MOST (and defined by the China National Bureau) to monitor levels of innovation within TBIs in China. The first measure is based on the number of approved intellectual property rights (AIPs) granted by industrial professional associations to firms within an incubator (e.g. for product designs, software copyright, printed circuit boards, or a new type of plant). This broad measure indicates innovations that may not be patentable, but take the form of modifications of practical value to the development and competitiveness of the business. The second narrower measure is based on the number of patents granted $(\mathrm{Pt})$ to firms within an incubator from patenting offices/authorities. The protection period provided by patents is generally longer than that for non-patentable intellectual property. The third measure is based on the number of national science and technology project grants (NSTPs) awarded to firms within an incubator. These grants are only awarded for high-level basic research and advanced applied research on key scientific aspects identified by the Chinese government. Supported firms typically receive several million Yuan from the Chinese government for which they are expected to deliver the kind of advanced innovations essential to China's future economic development. These three measures of innovation provide a more complete view of a TBI's innovation activity than would be possible using a single measure thereby enabling us to consider the effects of both TBI support services and selected external factors on different levels of innovation.

\section{Incubator services}

The following four TBI support services are aimed at assisting incubatees to invest successfully in either R\&D-driven advanced innovation or more incremental innovation involving the application of existing technologies (Fritsch and Slavtchev, 2011; Mian 1996; Barbero et al., 2013) as well as the knowledge needed to start a business. These are the main 
support services that are measured in the MOST database used to monitor TBI performance and as such, are an indication of the priorities of Chinese TBIs.

Technical service support. Technical service support refers to the shared laboratories, equipment, and research facilities provided by an incubator to enable firms gain access to affordable technical and scientific resources. We shall use the total amount that a TBI invests in setting up and running its public service platform to measure the scale of its technical service support to new technology-based enterprises.

Financial service support. A key determinant of the success of incubatees is likely to be the amount of investment in the $R \& D$ required for the successful development of innovative products and processes (Acs and Audretsch, 1988, Colombo et al., 2010, Perez-luno et al., 2011). The amount of incubator funding available to incubatees is used here to measure the level of financial service support. Incubator funding can be allocated as grant, loan or equity funding, payment for using external research facilities, and/or payment for IP applications, depending on the nature and ownership of the incubator.

Entrepreneurial service support. TBIs offer entrepreneurial assistance services to founding entrepreneurs who are likely to possess technological expertise but lack entrepreneurial experience. The number of entrepreneurs who provide entrepreneurial assistance to resident firms is used here to measure the scale of a TBI's entrepreneurial mentoring service.

Professional service support. TBIs typically provide a range of professional services to their resident firms such as advice on licensing, training, legal protection, patent searching and networking with key suppliers and customers. The scale of professional service support can be measured by the number of full-time employees in an incubator as it seems reasonable to assume that the more staff serving resident entrepreneurs, the greater the professional support available to facilitate innovation.

\section{Exogenous factors}

Influenced by the findings of previous research reported above, we have chosen to focus upon the following two key external factors which are likely to influence the innovation activity of incubatees.

Availability of venture capital. It is difficult to assess the amount of venture capital from different sources available to technology-based start-up firms in general and those located in TBIs in particular, especially in China where venture capital is in its nascent form and 
awareness of potential investment opportunities is heavily reliant on informal channels (Xiao and North, 2012). We therefore use the total amount of venture capital received by firms within each TBI to indicate the availability of venture capital within its host city/municipality.

Availability of scientific knowledge resources. We use the number of universities and colleges within the host city/municipality of each TBI to indicate the local availability of scientific knowledge resources given the absence of more detailed data on the specialisations and research strengths of universities. This simple measure captures the scale of scientific knowledge resources that are available to new ventures located in the city. Table 2 shows that the Eastern region accounts for almost 50 per cent of all the universities and colleges across China, indicating that technology-based enterprises in this region potentially have access to a greater supply of scientific knowledge resources than their counterparts in the Central and Western regions.

\section{Table 2 about here}

\section{Data sources and analysis}

This study is primarily concerned with a quantitative analysis of a large dataset covering TBIs throughout China, thereby providing information in a part of the world where the role of TBIs has been relatively unexplored previously. This unique dataset includes information on the awards and grants related to innovation obtained by resident firms within incubators as well as data relating to various incubator support services. However, whilst the use of this official dataset has the advantage of a breadth of coverage which is unlikely to be possible for academic researchers, it does lack detailed information on the type of support offered by Chinese TBIs in practice. For this reason, it was decided after preliminary analysis of the dataset to also undertake some primary research in China in order to enhance our understanding of the aims of Chinese TBIs and the nature of their support services relating to innovation. Nine case study TBIs were chosen and interviews carried out with both managers and entrepreneurs in each incubator. The more detailed insights gained from these interviews complemented the quantitative survey data and contributed to our interpretation of the results of the statistical modelling. We now describe each of our data sources in more detail.

Quantitative data: The data used in this study were taken from various sources. First, we used administrative data on all incubatees within each TBI in China collected by the MOST 
in five consecutive annual surveys undertaken between 2009 and 2013. This source provided data on the size (i.e. number of incubatees) in each TBI; the numbers of firms obtaining each of the three awards and grants used to differentiate levels of innovation; and data on the four types of incubator services ${ }^{1}$. Second, we collected data on the age (i.e. number of years from the first incubatee(s)) of all the TBIs from their websites. Third, we gathered data on city and municipal level characteristics from the official Statistical Yearbooks enabling us to calculate the number of universities and colleges in the host city/municipality of each TBI.

We have restricted our analysis to the 215 TBIs that existed in 2009 and were still in existence in 2013 i.e. had survived the five year period. Amongst these, 137 were located in the Eastern region, 45 in the Central region and 33 in the Western region. These 215 incubators accounted for 24,777 incubated firms in 2012. Of these, 14,420 (58 per cent) were located in the Eastern region, 6,876 (28 per cent) in the Central region and 3,481 (14 per cent) in the Western region. Our research has taken data from five consecutive annual surveys in order to iron out possible annual fluctuations in resource allocations by incubators as well as allowing time for some of the younger TBIs to become established and more advanced innovations to obtain legal protection. We have created a set of variables based on the annual average (mean) values over the five years across the 215 observations. Table 3 provides a summary of the definitions and descriptive statistics for the dependent, independent and control variables used in this study.

Table 3 about here

The hypotheses proposed earlier were estimated by the Maximise Likelihood Estimation (MLE) method and tested with negative binomial regression models for each set of independent variables ${ }^{2}$. We first conducted regression tests for the entire sample of TBIs across China and then repeated the models for each of the three mega regions to test for possible differences in the effects of TBI services and exogenous factors on the innovations of incubatees in the more and less developed Chinese regions.

\footnotetext{
${ }^{1}$ Face to face interviews with managers from the Torch High Technology Industry Development Centre China were conducted in July 2011 and again in June 2013 to discuss the definition of these measures and the data required by MOST.

${ }^{2}$ As the dependent variables are count data rather than continuous variables, negative binomial regression was the most appropriate model to use (an OLS regression could lead to inconsistent estimators and predictive values as it assumes continuous dependent variables).
} 
Qualitative data: We conducted 41 face-to-face interviews with TBI managers and resident entrepreneurs in nine TBI cases over a period of 18 months from 2015 to $2016^{3}$ (see Table 4). Table 5 shows the profile of the nine case studies all of which were drawn from four cities: Fushan, Guangzhou, Zhuhai, and Nanning and selected to give examples of different types of TBI ownership. The nine case studies include six state-owned TBIs, comprising two government ones and four university ones, and three privately-owned TBIs, comprising two corporate ones and one private one. TBI managers were asked about their aims, funding sources, engagement with industry, and specific support offered to assist the innovation activity of incubatees, whilst entrepreneurs were asked about the challenges they faced, their innovation support needs, and the nature of the support they received from the incubator's management and from external sources. Table 5 shows the characteristics of the nine selected cases, including their ownership type, aims, industry focus and revenue sources.

Table 4 about here

Table 5 about here

\section{Findings}

\section{Modelling results}

We now present the results of our statistical modelling based on the data relating to the 215 TBIs across China. For each of the three levels of innovation, we test first for the effects of the various support services (hypothesis 1) and then for the effects of the two external factors (hypothesis 2) on the three levels of innovation. We then test to see whether there are any differences in these relationships between TBIs in the three Chinese regions (hypothesis 3 ).

\section{(i) Approved intellectual property}

We focus first on the level of innovation measured by the number of AIPs granted, this being the broadest measure of innovation. In Table 7a, we report the results of the negative binomial regression analysis to examine the effects of incubator services and exogenous

\footnotetext{
${ }^{3}$ A professor from an elite university in Guangzhou, who is well networked with the Department of Science and Technology of Guangdong, arranged all the interview appointments for us. All the face to face interviews with directors of TBIs and entrepreneurs of firms were conducted by one of the authors who speaks both Chinese and English, being accompanied by the professor and his researchers. Each interview with TBI directors lasted 2 hours on average, including a tour of laboratories, open access and exhibition facilities, whilst each interview with resident entrepreneurs lasted 40 minutes.
} 
factors on the number of AIPs. Models 1 and 2 apply to the entire national sample of TBIs in existence between 2009 and 2013 and include the incubator-specific factors indicating the scale of the four types of service support provided and the control variables (i.e. incubator size and age). In model 2 we add the two exogenous factors (i.e. the amount of venture capital received by firms in each incubator and the number of universities and colleges within the host city/municipality).

The two models show that the amount of investment in technical service support (i.e. laboratories, equipment, technology training, competitions, and subsidisation of the costs of using external research facilities) is the only incubator-specific factor that has a significant $(p<0.05)$ and positive effect on the number of AIPs obtained by incubatees after controlling for incubator size and age. In other words, it is the technical service support from an incubator which contributes positively to innovation when this widest definition is used. Technical support, especially the provision of more generic laboratory facilities and equipment, is more directly associated with less advanced innovation activities than the other three support services. Neither financial, nor entrepreneurial, nor professional support has a significant effect on the number of AIPs obtained.

Table 6 about here

Unsurprisingly, the models also confirm that the number of AIPs is positively influenced by incubator size $(p<0.01)$, but not by incubator age. In terms of the exogenous factors, model 2 indicates that the amount of venture capital received by incubated firms does have a significant $(p<0.05)$ and positive effect on the number of AIPs, but that access to scientific knowledge resources does not.

\section{Table $7 \mathrm{a}$ about here}

We now repeat the above modelling procedure to see if there are any differences between the three regions in terms of the influences upon low order innovations as measured by AIPs. Models 3 and 4 relate to the incubators located in the Eastern region, models 5 and 6 to those in the Central region, and models 7 and 8 to those in the Western region. In models 3, 5, and 7 we include the incubator specific factors and the control variables whilst in models 4, 6, and 8 we add the two exogenous variables. Interestingly, there appear to be some regional differences. Models 3 and 4 for the Eastern region show that none of the TBI services have a significant effect on the number of AIPs and that it is only the amount of venture capital 
received by incubated firms that does have a significant $(\mathrm{p}<0.1)$ and positive effect. Models 5 and 6 for the Central region show a positive although fairly weak effect of incubator financial support on this broadest measure of innovation, but the effect disappears when the two exogenous variables are added. However, models 7 and 8 show that investment in the technical support services does significantly $(p<0.01)$ and positively influence the making of lower order innovations in the Western region. The amount of incubator funding available to incubatees also influences the number of AIPs positively and significantly $(p<0.1)$ when the two exogenous factors are added. Therefore, in contrast to the Eastern and Central regions, technical support from TBIs plays a more direct role in lower order innovation activity in the peripheral Western region. This suggests that direct technical support from incubators in this peripheral region compensates for a lack of other external resources and is therefore proving crucial to achieving incremental and modifying innovations in new technology-based enterprises. The number of AIPs is positively influenced by both incubator size $(p<0.05)$ and incubator age $(\mathrm{p}<0.05)$ in the Western region, suggesting that older TBIs are putting greater effort into achieving lower order innovations in their incubatees compared to their counterparts in more developed regions. A further indication of the difficulties of attracting external resources in the Western region is that the amount of $\mathrm{VC}$ received has a significant $(p<0.1)$ but negative effect on the number of AIPs. Unlike their counterparts in the Eastern region, investors appear to be avoiding the less innovative incubatees in the more peripheral region.

\section{(ii) Patents}

Models 9-16 in Table $7 \mathrm{~b}$ show the equivalent results for our second innovation measure i.e. the number of patents. The results for the entire national sample (models 9 and 10) again show that the amount of investment in technical service support is the only incubator factor that has a positive and significant $(\mathrm{p}<0.05)$ effect on the number of patents regardless of whether the two exogenous factors are added. Thus expenditure by TBIs on the provision of laboratory and research facilities and equipment appears to have a direct influence on the ability of incubatees to undertake innovations that are awarded patent protection. Somewhat surprisingly, neither of the two exogenous factors appears to significantly influence the number of patents that are awarded.

Table $7 \mathrm{~b}$ about here 
Models 11-16 show the equivalent results for the Eastern, Central, and Western regions respectively. Once again, the results differ between these regions. In the Eastern region, none of the TBI services nor the two exogenous factors are significantly associated with patented innovation activity. Incubator size is the only TBI feature to be statistically significant. However, for the TBIs in the Central region, several of their services appear to contribute positively to the making of patentable innovations. Expenditure on technical service support is found to have a positive and highly significant $(p<0.01)$ association with the number of patentable innovations regardless of whether the two exogenous factors are added. Also, both financial and entrepreneurial support are found to have positive though less significant $(\mathrm{p}<0.1)$ associations with the number patent innovations, although their effects disappear when the two exogenous factors are added. The amount of venture capital is also found to be significant $(p<0.05)$. Therefore, the activities of TBIs in the Central region do appear to be positively influencing the making of innovations protected by patents in their incubatees. In the Western region, it is only the amount of investment in technical services support that has a positive albeit fairly weak impact on the number of patentable innovations $(p<0.1)$, but even this effect disappears when exogenous factors are considered. Incubator age is the only other TBI attribute that has a significant positive influence confirming that these older TBIs in this least developed region are having an impact upon lower and intermediate order innovation activity in their incubatees.

\section{(i) National science and technology project awards}

Turning to consider the more advanced and R\&D intensive innovations as measured by the number of NSTP awards received by incubated firms, models 17 and 18 in Table 7c present the results for the entire national sample and models 19-26 for the three regions. For the entire sample, expenditure on technical service support has a positive and significant $(p<0.05)$ effect on the most advanced innovations regardless of whether the two exogenous factors are considered. The financial service support provided by TBIs also has a positive and significant effect $(p<0.1)$ but the effect disappears when the two exogenous factors are added. Interestingly, the amount of venture capital in incubatees appears to have no significant influence on the number national scientific and technology projects across China as a whole, unlike its influence on the number of lower order innovations.

The equivalent regional models again highlight important differences between the three regions. Incubator funding has a significant $(\mathrm{p}<0.05)$ and positive influence on the number of 
NSTP grants for the TBIs in the Eastern region (model 19), but the effect disappears when the two exogenous factors are included (model 20). As expected, the number of universities within the host city has a significant $(\mathrm{p}<0.05)$ and positive influence for the Eastern region, indicating that the local knowledge and skills base does have an important influence on more advanced innovation activity in this most developed region. For the Central region (models 21 and 22), incubator funding proves to be weakly significant $(\mathrm{p}<0.1)$ and positive, but the effect disappears when the two exogenous factors are added. Again, the number of universities within the city has a significant $(\mathrm{p}<0.05)$ and positive effect. For the Western region (models 23 and 24), it is only the financial support from the TBIs that has a significant, though fairly weak $(\mathrm{p}<0.1)$ influence on the making of more advanced innovations when the external factors are included in the regression. Here, the number of universities within the host city has a significant $(\mathrm{p}<0.05)$ but surprisingly negative influence.

Table 7c about here

All the models (Tables 7a, 7b, and 7c) show a consistent result in that the entrepreneurial service support and professional service support do not have a significant and positive effect on any of the three levels of innovation. This tends to support the view that these services are directed more towards assisting with other aspects of business development than with facilitating the development of innovations within incubatees.

The results of the modelling therefore provide partial support for hypotheses H1 and H2 in that the technical and financial support services together with both exogenous factors appear to have a positive influence on the various levels of innovation in incubated firms. Moreover, the support services of TBIs in the two less developed regions appear to have a more significant impact on the lower and intermediate order innovation activity of incubatees than that of their counterparts in the core region, providing some support for H3.

In terms of the local exogenous factors, the modelling found that the availability of venture capital was important for the financing of both patentable and non-patentable innovations, but not for the more advanced innovations. The uncertain outcomes and long lead times of conducting highly advanced innovations may deter Chinese private investors from investing in these high risk projects. This finding is consistent with previous research on the financing of high-tech SMEs in China that concluded that venture capital has yet to contribute significantly to their ability to develop distinctive and highly innovative technologies and products (Xiao and North, 2012). 


\section{Qualitative evidence}

Of the four incubator services that we examined, it is the amount of investment in the technical support services that is most likely to improve the ability of incubatees to innovate as measured by the number of both APIs and patents granted, although not as measured by the number of NSTP awards. In other words, investment in an incubator's shared facilities and equipment does appear to positively influence the making of lower and intermediate order innovations. The interviews with Chinese TBI managers shed more light on the form that technical support can take in practice.

Unlike many TBIs in Europe and the USA, Chinese TBIs tend to invest directly in their own laboratory, equipment and technical facilities rather than helping entrepreneurs build relationships with university scientists in order to gain access to laboratory resources. Stateowned TBIs in particular use their public funding to invest heavily in laboratories, equipment and technical facilities such as workspace, up-to-date data communication infrastructure, scientific and technical data sharing and condition guarantees. This can take the form of providing the more expensive specialist equipment and research facilities needed for making more advanced innovations and tailored to the needs of specific firms as well as the more generic facilities that can be shared amongst incubatees. Such provision compensates for the cost and difficulties of gaining access to the external research facilities needed to undertake R\&D and extended product testing, although some TBIs did subsidise the cost to firms of using external research facilities. Other TBIs offered talks by star scientists on the relevant technologies and ran technology-based competitions between incubatees in an effort to inspire firms to conduct innovation.

Consistent with the modelling results showing a significant relationship between the amount of financial service support available to incubatees and more advanced innovation activity, some TBI managers reported that they targeted financial assistance in the form of grants on those incubatees capable of breakthrough research and/or the potential to become future market leaders. For example a TBI director in Guangzhou commented that a significant proportion of their funding was allocated to a few firms that were developing advanced products and likely to become major market players. State-owned TBIs offered grants ranging from half a million to two million RMB to firms receiving NSTP awards or patents in order to recognise the potential of continuing innovations. Interviewed entrepreneurs confirmed that grants received from the TBI are crucial alongside the NSTP grants for 
engaging in this higher risk, more R\&D intensive innovation activity. In turn, the awards and grants from governments made them more attractive to possible private and employee investors. Similarly, whilst all nine TBIs made direct investments in the form of equity finance, they tended to concentrate on those incubatees judged to have the best growth prospects in the medium-long term. The returns on these investments were considered to be an important source of future income to help sustain the incubator. As well as these larger funding commitments, the case study TBIs typically offered smaller amounts of funding to their incubatees for covering the expenses involved in making applications for intellectual property protections, regardless of whether or not the applications were successful. There were also instances of financial incentives being given to firms in an effort to encourage them to obtain venture capital.

In terms of entrepreneurial support, the most common practice amongst the nine TBIs was to invite well-known, successful entrepreneurs and/or leading researchers to serve on the TBI board and to give talks and offer training courses on a regular base. These support practices may not contribute directly to innovation activity, but help to create an environment that is more conducive to adopting new ideas and for progressing and commercialising innovations. Moreover, some TBIs arranged visits to successful companies and potential clients in an effort to evaluate an innovations commercialisation prospects. Regarding professional support services, we found that common practices included liaising with local government to remove any legislative constraints on firms; helping incubatees win contracts; providing training on relevant policies; accessing legal and accounting services; and functioning as a welcoming community by offering accommodation and entertainments to business founders and their employees. State-owned TBIs are better able to leverage those resources controlled by governments through their relations with officials from national, provincial and local government compared to non-state TBIs. This evidence therefore confirms the results of the modelling in showing that both the entrepreneurial and professional support services provided by Chinese TBIs are focused more on supporting the development of successful enterprises rather than supporting innovation activity per se.

\section{Conclusions and implications}

This paper is one of the first studies to examine the role played by TBIs in supporting innovation by new technology-based business ventures in China, the world's second biggest economy. Whilst the four support services that we consider in this paper are well documented 
in the literature on TBIs in Western economies (Mian 1996; McCann and Folta, 2011; Fritsch and Slavtchev, 2011; Franklin et al., 2001), we consider their role within Chinese TBIs and the types of practices that each service covers in the Chinese context. Our particular focus in this paper has been on the influence that these support services make to the innovation activities of incubatees rather than to their graduation and subsequent growth. As well as distinguishing between four types of support service that TBIs provide, our research has distinguished between lower order innovations and more advanced R\&D intensive innovations, employing three innovation measures as used by the Chinese authorities.

Across China as a whole, our modelling results show that there is a relationship between the services provided by TBIs and the level of innovation undertaken by incubated firms. In particular, spending on an incubator's shared physical research facilities and equipment stands out as having a positive influence on the making of all levels of innovation. The provision of fairly basic and generic facilities and equipment that can be shared by all incubatees is clearly important for engaging in lower order innovation activity whereas investment in more specialist facilities by some TBIs contributes to achieving more advanced, R\&D intensive innovations. Our evidence indicates that Chinese TBIs place greater emphasis on direct investment in laboratory space and equipment themselves than their Western counterparts who increasingly focus on helping business founders gain access to these resources externally. Historically the state owned TBIs in China have targeted university academics and graduates with new product ideas and provided the physical resources to enable them to develop their innovations to a point where a viable business is created. Direct financial support from Chinese TBIs appears to have some influence on the level of innovation activity carried out by incubatees, being most associated with the more advanced innovations qualifying for NSTP awards. As evident from the case studies, it is often the intention of TBI managers to focus their financial assistance on those firms which they consider to have the potential to become leading market players, not least because it helps to sustain the TBI as well as boost its self-image and reputation. Neither entrepreneurial nor professional support appear to have a direct influence on the scale or level of innovation activity, both being more focused on helping founding entrepreneurs with other aspects of building viable businesses.

Unlike some previous work, this study has not been confined to the influence of TBI services but has recognised the possible influence of other exogenous factors on the levels of innovation found amongst TBI incubatees. Using surrogate measures, we have been able to 
build the availability of venture capital and local scientific resources into the regression modelling. The findings confirm that the availability of venture capital has a greater influence on the making of lower order than higher order innovations. This is consistent with other recent evidence (Xiao and North, 2012) showing the reluctance by Chinese private investors to make higher risk investments that may take several years to yield a return. Although across China as a whole, the scale of scientific knowledge resources from nearby universities appears not to have a significant influence on the scale or type of innovation activity in incubatees, it is a significant influence on producing more advanced innovations in the Eastern region, possibly reflecting the more leading edge scientific and technical research undertaken by some universities in this most developed part of China.

The use of a national dataset comprising 215 TBIs distributed across China has enabled us to advance our understanding of how the roles performed by TBIs can differ depending on the regional context. We provide some evidence to support the notion that TBIs make regional adaptations, depending on the availability of other local resources. We have been able to point to certain differences in the roles performed by TBIs in China's three mega regions, reflecting the uneven distribution of the resources needed for business innovation throughout China. Although more than two thirds of China's TBIs are to be found in the more developed Eastern region, it is those TBIs in the less developed Central and Western regions, where the resources to support new innovative ventures are scarce, that are making a positive difference to the scale of lower and intermediate order innovation activity amongst incubatees. However, direct financial support from TBIs has a positive influence on innovations qualifying for NSTP awards in the Eastern region and in the Central and Western regions to lesser extents. As evident from the interviews with TBI managers, incubators in the more developed and successful Eastern region are particularly concerned with enabling founding entrepreneurs leverage local resources such as venture capital through the use of financial incentives. In these respects our research provides some evidence of regional adaptability in the development of Chinese TBIs as they adjust their roles to diverse economic contexts (Dutt et al., 2016).

Given the exploratory nature of this study, it can only be indicative of a number of factors influencing the innovation performance of business ventures in Chinese TBIs which need to be investigated further in future research. Whilst this research has been able to draw upon a unique data base, covering the population of TBIs in China, it has been constrained by the various measures that TBI managers are required to record by the MOST. For instance, it is 
the amount spent on each incubator support service that has been recorded, rather than the amount spent on detailed sub-services and the difference these make to innovation performance. Another limitation is that the MOST dataset does not contain any information about the sectoral composition of TBI incubatees, yet this is likely to be a key influence on the nature of the innovation process and the support services required (Schwartz and Hornych, 2008); for example, incubatees in the research intensive bio-tech sector are likely to require more specialised laboratory facilities and greater financial investment than those in the digital electronics sector. Unfortunately, information relating to the origins of the entrepreneurs and characteristics of businesses that have entered the incubator and could have a bearing on the innovations undertaken is also lacking from the dataset. These are the kinds of issues that can only be addressed by more in-depth primary research focused on a representative sample of TBIs within different regional contexts.

As has been shown in Europe, different incubation strategies and models are needed for different environments and what proves successful in one environment, region, or context cannot be merely imitated in another (Clarysee et al., 2005). Clearly more in depth empirical research is needed in China in order to better understand how the goals, strategies, and services of TBIs are best adapted to particular geographical circumstances. In other words, future policies regarding the evolution of TBIs in China need to be attuned to different regional contexts and the uneven spatial distribution of resources needed for business innovation, even to the extent of developing different TBI models to fit specific regional circumstances.

More generally, it is our view that TBIs have the potential to play an important role in China's transition from being reliant on technological imports and imitation-based competitive strategies of technology followers to being able to generate more technology leaders capable of making more advanced and radical innovations (Xiao et al., 2013; Zhu et al., 2012). However, this is likely to require a greater focus on the establishment of sectorspecialised incubators with the resources, expertise, and networks to encourage and support the creation of new ventures capable of undertaking more advanced innovations than has been the case hitherto.

\section{References}


Acs Z. J. and Audretsch D.B. (1988) Innovation in large and small firms: an empirical analysis, American Economic Review 78, 678-690.

Adkins D. (2002) A brief history of business incubation in the United States. Athens, Ohio: National Business Incubation Association

Aerts K., Matthyssens P. and Vandenbempt K. (2007) Critical role and screening practices of European business incubators. Technovation 27, 254-267.

Ahlstom D. and Bruton G. (2010) Rapid institutional shifts and the co-evolution of entrepreneurial firms in transitional economies, Entrepreneurship Theory and Practice 34, 531-554.

Ahlstrom D. and Ding Z. (2014) Entrepreneurship in China: an overview, International Small Business Journal 32.6, 610-618.

Allen D. and Rehman S. (1985) Small business incubators: a positive environment for entrepreneurship, Journal of Small Business Management (July), 12-24.

Amezcua A. S. Grimes M. G. Bradley S. W. and Wiklund J. (2013) Organizational sponsorship and founding environments: a contingency view on the survival of businessincubated firms, 1994-2007. Academy of Management Journal 56, 1628-1654

Athreye S.S. and Keeble, D. (2002) Sources of increasing return and regional innovation in the UK. Regional Studies 36, 345-357.

Barbero J.L. Casillas J.C. Wright M and Garcia A.R. (2013) Do different types of incubators produce different types of innovation? J Technol Transf published online

Bergek A. and Norrman C. (2008) Incubator best practice: a framework. Technovation 28, 20-28.

Berry A.J., Sweeting R., and Goto J. (2006) The effect of business advisors on the performance of SMEs. Journal of Small Business and Enterprise Development 13, 33-47.

Bruneel J., Ratinho T., Clarysse B., and Groen A. (2012) The evolution of business incubators: comparing demand and supply of business incubation services across different incubator generations. Technovation 32, 110-121.

Bøllingtoft A. and Ulhøi J. P. (2005) The networked business incubator-leveraging entrepreneurial agency, Journal of Business Venturing 20, 265-290.

Chan K. F. and Lau T. (2005) Assessing technology incubator programs in the science park: the good, the bad and the ugly, Technovation 25, 1215-1228.

Clarysee B., Wright M., Lockett A., Velde E.V. de and Vohora A. (2005) Spinning out new ventures: a typology of incubation strategies from European research institutions. Journal of Business Venturing 20, 183-216. 
Colombo M.G. and Delmastro M. (2002) How effective are technology incubators? Evidence from Italy. Research Policy 31, 1103-1122.

Colombo M. G., Luukkoner T., Mustart P., and Wright M. (2010) Introduction: venture capital and high-tech start-ups. Venture Capital 12, 261-266.

Colombo M.G, Piva E., and Rentocchinin F. (2012) The effects of incubation on academic and non-academic high-tech start-ups: evidence from Italy. Economics of Innovation and New Technology 21, 505-527.

Cooke P. (2001) Knowledge Economics: Clusters, Learning and Cooperative Advantage. Routledge, London.

Dee N.J., Livesey F., Gill D., and Minshall T. (2011) Incubation for Growth: A Review of the Impact of Business Incubation on New Ventures with Growth Potential, NESTA, London.

Dutt N. Hawn O. Vidal A. McGahan A. and Mitchell W. (2016) How open system intermediaries address institutional failures: the case of business incubators in emergingmarket countries. Academy of Management Journal 59, 818-840

Etzkowitz H. Carvalho de Mello J. M. and Almeida M. (2005) Towards "meta-innovation" in Brazil: the evolution of the incubator and the emergence of a triple helix. Research Policy 34, 411-424.

Ferguson R. and Olofsson C. (2004) Science parks and the development of NTBFs location, survival and growth. The Journal of Technology Transfer 29, 5-7.

Fernández Fernández M. T. Blanco Jimenez F. J. and Cuadrado Roura J. R. (2015) Business incubation: innovative services in an entrepreneurship ecosystem. The Service Industries Journal 35, 783-800.

Folta T., Cooper A. C., and Baik Y-s (2006) Geographic cluster size and firm performance. Journal of Business Venturing21, 217-242.Franklin S.J. Wright M and Lockett A. (2001) Academic and surrogate entrepreneurs in university spin-out companies. The Journal of Technology Transfer 26, 127-141

Fritsch M. and Mueller P. (2004) Effects of new business formation on regional development over time. Regional Studies 38, 961-975.

Fritsch M. and Slavtchev. (2011) Determinants of the efficiency of regional innovation systems. Regional Studies 45, 905-918.

George G. Zahra S.A. Wood Jr. (2002) The effects of business-university alliances on innovation output and financial performance: a study of publicly traded biotechnology companies. Journal of Business Venturing 17, 577-609.

Grimaldi R. and Grandi A. (2005) Business incubators and new ventures creation: an assessment of incubating models. Technovation 25, 111-121. 
Grimaldi R. Kenney M. Siegel D. and Wright M. (2011) 30 years after Bayh-Dole: reassessing academic entrepreneurship. Research Policy 40, 1045-1057.

Hackett S. M. and Dilts D. M. (2004) Areal options-driven theory of business incubation. Journal of Technology Transfer 29, 41-54.

Hendry C., Brown J. and Defillippi R. (2000) Regional clustering of high technology-based firms: opto-electronics in three countries. Regional Studies 34, 129-144.

Henson M.T., Chesbrough H.W. Nohria N. Sull D.N. (2000) Networked incubators. Hothouses of the new economy. Harvard Business Review, 78(5), 74-84.

Henson N. (1992) Competition, trust, and reciprocity in the development of innovation regional milieu. Regional Science 71, 95-105.

Hisrich R. and Smilor R. (1988) The university and business incubation: technology transfer through entrepreneurial development. Technology Transfer (Fall 1988), 14-19.

Hong W. (2008) Decline of the centre: the decentralizing process of knowledge transfer of Chinese universities from 1985 to 2004, Research Policy 37, 580-595.

Jauhiainen J.S. (2008) Regional and innovation policies in Finland - towards convergence and/or mismatch?, Regional Studies 42, 1031-1045.

Keeble D. (1997) Small firms, innovation and regional development in Britain in the 1990s. Regional Studies 31, 281-293.

Kuratko, D.F. and LaFollette W.R. (1987) Small business incubators for local economic development, Economic Development Review 5, 49-55.

Lalkaka R. and Bishop J. (1996) Business incubators in economic development: an initial assessment in industrial countries, New York, United Nations Development Programme

Lee C., Lee K. and Pennings J.M. (2001) Internal capabilities, external networks, and performance: a study on technology-based ventures, Strategic Management Journal 22, 615640.

Lee S.S and Osteryoung J.S. (2004) A comparison of critical success factors for effective operations of university business incubators in the United States and Korea. Journal of Small Business Management 42, 418-426.

Li J. (2015) Bridging the equity funding gap in technological entrepreneurship: the case of government-backed venture capital in China, in J.G. Hussain and J.M. Scott (eds) Research Handbook on Entrepreneurial Finance, Edward Elgar, Cheltenham.

Liu X. and White S. (2001) Comparing innovation systems: a framework and application to China's transitional context. Research Policy 30, 1091-1114

Lockett A. and Wright M. (2005) Resources, capabilities, risk capital and the creation of university spin-put companies Research Policy 34, 1043-1057. 
Lofsten H. and Lindelof P. (2002) Science parks and growth of new technology based firms: academic-industrial links, innovation and markets. Research Policy 31, 859-876.

Mansury M. A. and Love J. H. (2008) Innovation, productivity and growth in US business services: a firm-level analysis, Technovation 28, 52-62.

Markman G. D., Phan P. H., Balkin D. B. and Gianiodis P. T. (2005) Entrepreneurship and university-based technology transfer. Journal of Business Venturing 20, 241-263.

McAdam M. and McAdam, R. (2008) High tech start-ups in University science park incubators: the relationship between the start-up's lifecycle progression and use of the incubator's resources. Technovation 28, 277-290.

McCann B. T. and Folta T. B. (2011) Performance differentials within geographic cluster. Journal of Business Venturing 26, 104-123.

Mian S. A. (1996) Assessing value-added contributions of university technology business incubators to tenant firms. Research Policy 25, 325-335.

Mian S. A Lamine W. and Fayolle A. (2016) Technology Business Incubation: An overview of the State of Knowledge. Technovation 50-51, 1-12

Meyer M (2003) Academic entrepreneurs or entrepreneurial academics? Research-based ventures and public support mechanisms. $R \& D$ Management 33 107-115

NBIA (2007) Business Incubation FAQ

OECD (2007) Reviews of innovation policy: China

North D. and Smallbone D. (2000) The innovation and growth of rural SMEs during the 1990s. Regional Studies 34, 145-57.

Pauwels C. Clarysse B. Wright M. Hove J. V. (2016) Understanding a new generation incubation model: the accelerator. Technovation 50-51, 13-24

Perez-Luno A. Wilklund J. and Cabrera R. V. (2011) The dual nature of innovation activity: how entrepreneurial orientation influences innovation generation and adoption. Journal of Business Venturing 26, 555-571.

Phan P.H. Siegel D. Wright M. (2005) Science parks and incubators: observations, synthesis and future research. Journal of Business Venturing 20, 165-182.

Powers J. B. and McDougall P. (2005) Policy orientation effects on performance with licensing to start-ups and small companies. Research Policy 34, 1028-1048.

Ratinho T. and Henriques E. (2010) The role of science parks and business incubators in converging countries: evidence from Portugal. Technovation 30, 278-290.

Rice M.P. (2002) Co-production of business assistance in business incubators An exploratory study. Journal of Business Venturing 17, 163-187 
Rothaermel F. and Thursby M. (2005) University-incubator firm knowledge flows: assessing their impact on incubator firm performance. Research Policy 34, 305-324.

Rothwell R. and Zegveld W. (1982) Innovation and the Small and Medium Sized Firm, Frances Pinter, London.

Rubin, T.H., Aas T.H., and Stead A. (2015) Knowledge flow in Technological Business Incubators: Evidence from Australia and Israel. Technovation 41-42, 11-24.

Salvador E. (2011) Are science parks and incubators good "brand names" for spin-offs? The case study of Turin, Journal Technol Transf 36, 203-232.

Schwartz, M. and Hornych, C. (2008) Specialisation as strategy for business incubators: an assessment of the Central German Multimedia Centre. Technovation 28 (7), 436-449.

Shane, S. \& Cable, D. (2002). Network ties, reputation, and the financing of new ventures, Management Science, 48, pp. 364-81.

Siegel D.S., Waldman D., Link D. (2003) Assessing the impact of organisational practices on the productivity of university technology transfer office: an exploratory study, Research Policy 32, 27-48.

Siegel D.S., Waldman D., Atwater L. E. and Link D. (2004) Towards a model of the effective transfer of scientific knowledge from academicians to practitioners: qualitative evidence from the commercialisation of university technologies. Journal of Engineering and Technology Management 21, 115-142.

Siegel, D. S. Wright M. \& Lockett A. (2007) The rise of entrepreneurial activity at universities: Organizational and societal implications, Industrial and Corporate Change 16, 489-504.

Smilor R. (1987) Managing the incubator system: critical success factors to accelerate new company development, IEEE Transaction on Engineering Management 34, 146-155.

Smith, D.J. and Zhang, M. (2012) Introduction: the evolution of the incubator concept, Entrepreneurship and Innovation 13.4, 227-234.

Smith L. H. and Bagchi-Sen S. (2012) The research university, entrepreneurship and regional development: research propositions and current evidence, Entrepreneurship \& Regional Development 24, 383-404.

Storper, M. (1995) The resurgence of regional economies, ten years later: the region as a nexus of untraded interdependencies, European Urban and Regional Studies 2, 191221.

Tellis, GJ. Prabhu JC. and Chandy RK. (2009) Radical innovation across nations: the preeminence of corporate culture, Journal of Marketing 73, 3-23. 
Theodorakopoulos, N., Kakabadse N., and McGowan, C. (2014) What matters in business incubation? A literature review and a suggestion for situated theorizing, Journal of Small Business and Enterprise Development, 21.4, 602-622.

Thierstein A. and Willhelm B. (2001) Incubator, technology, and innovation centres in Switzerland: features and policy implications, Entrepreneurship \& Regional Development 13, 315-331.

Tödtling F., and Kaufmann A. (2001) The role of the region for innovation activities of SMEs, European Urban and Regional Studies 8, 203-215.

Varis M. and Littunen H. (2010) Types of innovation, sources of information and performance in entrepreneurial SMEs. European Journal of Innovation Management 13, 128154.

Wright M., Birley S. and Mosey S. (2004) The formation of high tech university spinout companies: the role of joint ventures and venture capital investors. Journal of Technology Transfer 29, 287-310.

Wright M, Liu X, Buck T, Filatotchev I. (2008) Returnee entrepreneurs, science park location choice and performance: an analysis of high-technology SMEs in China. Entrepreneurship: Theory and Practice 32, 131-55.

World Bank (2002) Incubators in developing countries: status and development perspective. Washington DC.

Xiao L. and Ritchie B. (2009) Access to finance for high-tech SMEs: regional differences in China. Environment and Planning C: Government and Policy 27, 246-262.

Xiao L. and North D. (2012) Institutional transition and the financing of high-tech SMEs in China: a longitudinal perspective. Venture Capital 14, 1-19.

Xiao L. and North D. (2016) The graduation performance of technology business incubators in China' three tier cities: the role of incubator funding, technical support, and entrepreneurial mentoring. Journal of Technology Transfer DOI 10.1007/s10961-016-9493-4

Xiao L and Ramsden (2016) Founder expertise, strategic choices, formation and survival of high-tech SMEs in China: a resource-substitution approach. Journal of Small Business Management 54, 892-911

Xiao Y., Tylecote A., and Liu J. (2013) Why not greater catch-up by Chinese firms? The impact of IPR, corporate governance and technology intensity on late-comer strategies. Research Policy 42, 749-764.

Zhang F. Cooke P. and Wu F. (2011) State-sponsored research and development: a case study of China's biotechnology. Regional Studies 45, 575-595.

Zhu Y., Wittmann X. and Peng M. (2012) Institution-based barriers to innovation in SMEs in China, Asia Pacific Journal of Management, 29, 1131-1142. 
Table1 TBIs and incubated firms by region

\begin{tabular}{|c|c|c|c|c|c|c|c|c|c|c|}
\hline \multirow[b]{3}{*}{ Region } & \multicolumn{4}{|c|}{2009} & \multicolumn{4}{|c|}{2012} & \multicolumn{2}{|c|}{ 2009-2012 growth (\%) } \\
\hline & \multirow{2}{*}{\multicolumn{2}{|c|}{$\begin{array}{cc} & \text { TBI } \\
\text { No. } \quad \text { Proportion of China }\end{array}$}} & \multicolumn{2}{|r|}{ Firms } & \multicolumn{2}{|r|}{ TBI } & \multicolumn{2}{|r|}{ Firms } & \multirow[t]{2}{*}{ TBI } & \multirow[t]{2}{*}{ Firms } \\
\hline & & & No. & Proportion of China & No. & Proportion of China & No. & Proportion of China & & \\
\hline Eastern & 145 & 0.64 & 15591 & 0.56 & 256 & 0.68 & 25036 & 0.63 & 76.6 & 60.6 \\
\hline Western & 36 & 0.16 & 5168 & 0.19 & 52 & 0.14 & 5724 & 0.14 & 44.4 & 10.8 \\
\hline China & 228 & 1 & 27920 & 1 & 378 & 1 & 39635 & 1 & 65.8 & 42.0 \\
\hline
\end{tabular}

Note: calculated according to survey data by Ministry of Science and Technology from 2009 to 2012 
Table 2 University by region

\begin{tabular}{lcrrrrc}
\hline & Total & & \multicolumn{2}{l}{ University } & \multicolumn{2}{c}{ College } \\
& No. & Percentage & No. & Percentage & No. & Percentage \\
\hline Eastern & 856 & 49 & 353 & 51 & 503 & 48 \\
Central & 469 & 27 & 176 & 26 & 293 & 28 \\
Western & 416 & 24 & 157 & 23 & 259 & 25 \\
\hline China & 1741 & & 686 & & 1055 &
\end{tabular}

Note: calculated according to Statistics Yearbooks 2012 by governments at national, provincial, and city level. 
Table 3 Variable definition and summary statistics (average value of four years 2009-2013)

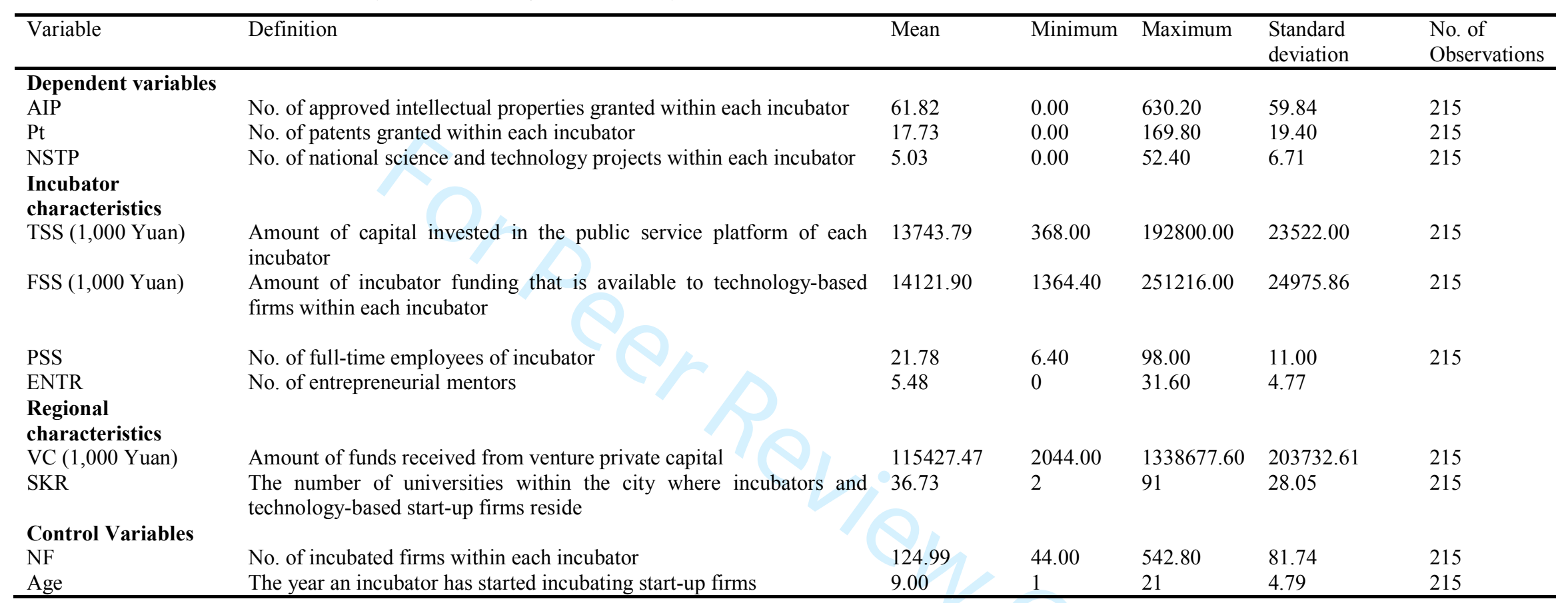


2

Table 4 Profile of nine cases

\begin{tabular}{|l|l|l|l|l|l|}
\hline Case & Year established & Location 1 & Location 2 & No of interviews & \\
\hline & & & & Managers of TBI & Entrepreneurs \\
\hline 1 & 2014 & Science park & Fushan & 2 & 3 \\
\hline 2 & 2014 & & & & 3 \\
\hline 3 & 2011 & Science park & Fushan & 1 & 3 \\
\hline 4 & 2011 & Industrial estate & Fushan & 1 & 3 \\
\hline 5 & 2010 & Science park & Fushan & 2 & 3 \\
\hline 6 & 2015 & Science park & Guangzhou & 1 & 3 \\
\hline 7 & 2001 & Science park & Guangzhou & 1 & 1 \\
\hline 8 & 2002 & Science park & Nanning & 2 & 4 \\
\hline 9 & 2009 & Science park & Zhuhai & 2 & 4 \\
\hline & & Science park & Guangzhou & 2 & 27 \\
\hline
\end{tabular}


Table 5: Characteristics of the cases

\begin{tabular}{|c|c|c|c|c|c|}
\hline Case & Name & Types & Aim & Industry focus & Sources of revenue \\
\hline 1 & $\begin{array}{l}\text { CNC Guangdong University } \\
\text { of Technology }\end{array}$ & UBI & $\begin{array}{l}\text { To set up computerised numerical control for ceramic } \\
\text { manufacturing }\end{array}$ & $\begin{array}{l}\text { computerised numerical } \\
\text { control }\end{array}$ & $\begin{array}{l}\text {-mainly publicly } \\
\text { funded } \\
\text {-fees/rent } \\
\text {-equity, early exit }\end{array}$ \\
\hline 2 & $\begin{array}{l}\text { Guangdong Leaguer } \\
\text { Innovation Tech }\end{array}$ & UBI & $\begin{array}{l}\text { Being invited by local government to set up a TBI and attract } \\
\text { technological entrepreneurs to create new ventures }\end{array}$ & $\begin{array}{l}\text { Advanced material and } \\
\text { related industry }\end{array}$ & $\begin{array}{l}\text {-mainly publicly } \\
\text { funded } \\
\text {-fees/rent/equity }\end{array}$ \\
\hline 3 & New Media & $\mathrm{PBI}$ & To recycle the abandoned plants, rent-seeking & $\begin{array}{l}\text { Mixed mainly on ceramic } \\
\text { and furniture }\end{array}$ & $\begin{array}{l}\text {-mainly on } \\
\text { fees+rent+equity } \\
\text {-government grants }\end{array}$ \\
\hline 4 & $\begin{array}{l}\text { Guangdong Lighting } \\
\text { Incubator }\end{array}$ & $\mathrm{GBI}$ & $\begin{array}{l}\text { To produce innovative products built upon regional strengths of } \\
\text { lighting source industry }\end{array}$ & $\begin{array}{l}\text { new lighting source } \\
\text { industry }\end{array}$ & $\begin{array}{l}\text {-mainly publicly } \\
\text { funded } \\
\text {-fees+rent } \\
\text {-equity, early exit }\end{array}$ \\
\hline 5 & $\begin{array}{l}\text { South China New Material } \\
\text { Incubator }\end{array}$ & $\mathrm{CBI}$ & $\begin{array}{l}\text { To closely work with new potential competitors and source new } \\
\text { ideas }\end{array}$ & new materials & $\begin{array}{l}\text {-mainly on } \\
\text { fees+rent+equity } \\
\text {-government grants }\end{array}$ \\
\hline 6 & DAAN incubator & $\mathrm{CBI}$ & $\begin{array}{l}\text { to invest in new ventures with significant growth potential } \\
\text { operating in the same industry }\end{array}$ & healthcare machinery & $\begin{array}{l}\text {-mainly on fees+equity } \\
\text {-government grants }\end{array}$ \\
\hline 7 & Nanning Tech Incubator & GBI & To develop a technology cluster for local economic growth & mixed & $\begin{array}{l}\text { mainly publicly funded } \\
\text {-fees+rent } \\
\text {-equity, early exit }\end{array}$ \\
\hline 8 & Tsinghua Zhuhai Incubator & UBI & To develop a technology industry cluster for local economic growth & drone and new materials & $\begin{array}{l}\text { mainly publicly funded } \\
\text {-fees+rent } \\
\text {-equity }\end{array}$ \\
\hline 9 & $\begin{array}{l}\text { Health incubator } \\
\text { GD Pharmaceutical university }\end{array}$ & UBI & To build a regional health industry chain & $\begin{array}{l}\text { Healthcare and related } \\
\text { industry }\end{array}$ & $\begin{array}{l}\text { mainly publicly funded } \\
\text {-fees+rent } \\
\text {-equity, early exit }\end{array}$ \\
\hline
\end{tabular}

Note: $\mathrm{UBI}=$ university business incubator, $\mathrm{PBI}=$ private business incubator, $\mathrm{CBI}=$ Corporate business incubator, $\mathrm{GBI}=$ government business incubator 
Table 6: Specific support services and constructs identified within empirical evidence

\begin{tabular}{lll}
\hline Services & Constructs & Offered by cases \\
\hline \multirow{3}{*}{ Technical support } & Labs with expensive equipment & $1,4,7,8$, and 9 \\
& Lab with basic facilities & 3, and 5 \\
& Talks by star scientists on technologies and their application & 2,5 , and 8 \\
& Technology-based competitions & 4 \\
& Covering the expenses involving in making IP application & $1,4,8$, and 9 \\
& Partial costs of using external research facilities & 4 \\
Financial support & Equity finance with clear ownership & $2,3,5,6$, and 8 \\
& Equity finance with blur ownership & $1,4,7$, and 9 \\
& Grant to those capable of breakthrough research & 1,4, and 7 \\
& Financial incentive to clients & 1 and 4 \\
& Financial incentive to firms obtaining VC & 8 and 9 \\
& Talks by well-known entrepreneurs & $1-5$ and $7-9$ \\
& Training courses offered by researchers & 2 and 4 \\
& Visiting successful companies and potential clients & 1 and 6 \\
& One to one session if it is required & 4 and 9 \\
& Networking (meeting clients and investors) & $1,2,4,6$, and 7
\end{tabular}


Table 7a Regression analyses of effects of regional and incubators' characteristics on Approved Intellectual Property (AIP)

\begin{tabular}{|c|c|c|c|c|c|c|c|c|}
\hline \multirow[b]{3}{*}{ Variables } & Model 1 & Model 2 & Model3 & Model 4 & Model 5 & Model 6 & Model 7 & Model 8 \\
\hline & $\begin{array}{l}\text { Coefficient } \\
\text { t-stats }\end{array}$ & $\begin{array}{l}\text { Coefficient } \\
\text { t-stats }\end{array}$ & $\begin{array}{l}\text { Coefficient } \\
\text { t-stats }\end{array}$ & $\begin{array}{l}\text { Coefficient } \\
\text { t-stats }\end{array}$ & $\begin{array}{l}\text { Coefficient } \\
\text { t-stats }\end{array}$ & $\begin{array}{l}\text { Coefficient } \\
\text { t-stats }\end{array}$ & $\begin{array}{l}\text { Coefficient } \\
\text { t-stats }\end{array}$ & $\begin{array}{l}\text { Coefficient } \\
\text { t-stats }\end{array}$ \\
\hline & Entire sample & & Eastern & & Central & & Western & \\
\hline Constant & $\begin{array}{l}3.614 \\
(21.97) * * *\end{array}$ & $\begin{array}{l}3.613 \\
(17.63)^{* * *}\end{array}$ & $\begin{array}{l}3.657 \\
(17.85)^{* * *}\end{array}$ & $\begin{array}{l}3.518 \\
(11.75)^{* * *}\end{array}$ & $\begin{array}{l}2.941 \\
(5.69)^{* * *}\end{array}$ & $\begin{array}{l}3.203 \\
(5.56)^{* * *}\end{array}$ & $3.115(11.98) * * *$ & $2.661(7.97)^{* * *}$ \\
\hline Incubator & & & & & & & & \\
\hline $\begin{array}{l}\text { TSS } \\
(1,000 \text { Yuan) }\end{array}$ & $6.37(2.25)^{* *}$ & $6.37(2.25)^{* *}$ & $3.692(.76)$ & $3.032(.48)$ & $5.629(1.36)$ & $4.728(1.15)$ & $30.315(3.13)^{* * *}$ & $29.697) * * *$ \\
\hline $\begin{array}{l}\text { FSS } \\
(1,000 \text { Yuan) }\end{array}$ & $2.567(.96)$ & $2.568(.96)$ & $3.288(.52)$ & $4.061(.83)$ & $-1.8339(-.32)$ & $-.6700(-.11)$ & $9.895(1.52)$ & $11.562(1.85)^{* *}$ \\
\hline ENTR & $-.0012(-0.09)$ & $-.0016(-.08)$ & $.0031(.18)$ & $.0041(.23)$ & $.0150(.59)$ & $.0068(.25)$ & $-.0328(-1.17)$ & $-.0096(-.33)$ \\
\hline $\begin{array}{l}\text { PSS } \\
\text { Reoion }\end{array}$ & $-.0003(-.06)$ & $-.0003(-.06)$ & $-.0003(-.05)$ & $-.0000(-.00)$ & $-.0139(-.77)$ & $-.0131(-.71)$ & $-.0055(-.61)$ & $-.0101(-1.17)$ \\
\hline $\begin{array}{l}\text { Region } \\
\text { VC (1,000Yuan) }\end{array}$ & $.1912(2.25)^{* *}$ & $\begin{array}{l}.1913 \\
(2.20)^{* *}\end{array}$ & $.1352(1.67)^{*}$ & $.1290(1.55)$ & $.6743(1.28)$ & $.5990(1.14)$ & $-1.697(-1.83)^{*}$ & $\begin{array}{l}-1.982(- \\
2.30) * *\end{array}$ \\
\hline $\begin{array}{l}\text { SKR } \\
\text { Control variable }\end{array}$ & $-.0008(-.39)$ & $-.0008(-.35)$ & $-.0003(-.14)$ & $.0005(.17)$ & $.0054(.96)$ & $.0032(.55)$ & $.0005(.11)$ & $.0014(.31)$ \\
\hline NF & $\begin{array}{l}.0027 \\
(3.26)^{* * *}\end{array}$ & $\begin{array}{l}.0027 \\
(3.24)^{* * *}\end{array}$ & $\begin{array}{l}.0046 \\
(3.35)^{* * *}\end{array}$ & $\begin{array}{l}.0047 \\
(3.39)^{* * *}\end{array}$ & $.0027(1.64)$ & $.0028(1.73)^{*}$ & $.0024(2.09)^{* *}$ & $.0021(1.97)^{* *}$ \\
\hline $\begin{array}{l}\text { Age } \\
\text { Type=Private }\end{array}$ & $.0022(.17)$ & $.0028(.16)$ & $-.0182(-.13)$ & $-.0225(-.17)$ & $.0448(1.32)$ & $.0575(1.57)$ & $.0417(2.16)^{* *}$ & $.0355(1.93)^{*}$ \\
\hline Government & & $.0004(.00)$ & & $.1434(.76)$ & & $-.348(-1.01)$ & & $.542(1.96)^{*}$ \\
\hline University & & $-.0012(-.01)$ & & $.0856(.33)$ & & $-.118(-.22)$ & & $.537(1.26)$ \\
\hline Pseudo-R ${ }^{2}$ & .039 & .039 & .025 & .026 & .059 & .062 & .221 & .238 \\
\hline $\begin{array}{ll}\begin{array}{l}\text { No. } \\
\text { observations }\end{array} & \text { of } \\
\end{array}$ & 215 & 215 & 137 & 137 & 48 & 48 & 30 & 30 \\
\hline
\end{tabular}


Table 7b Regression analyses of effects of regional and incubators' characteristics on Patents (Ps)

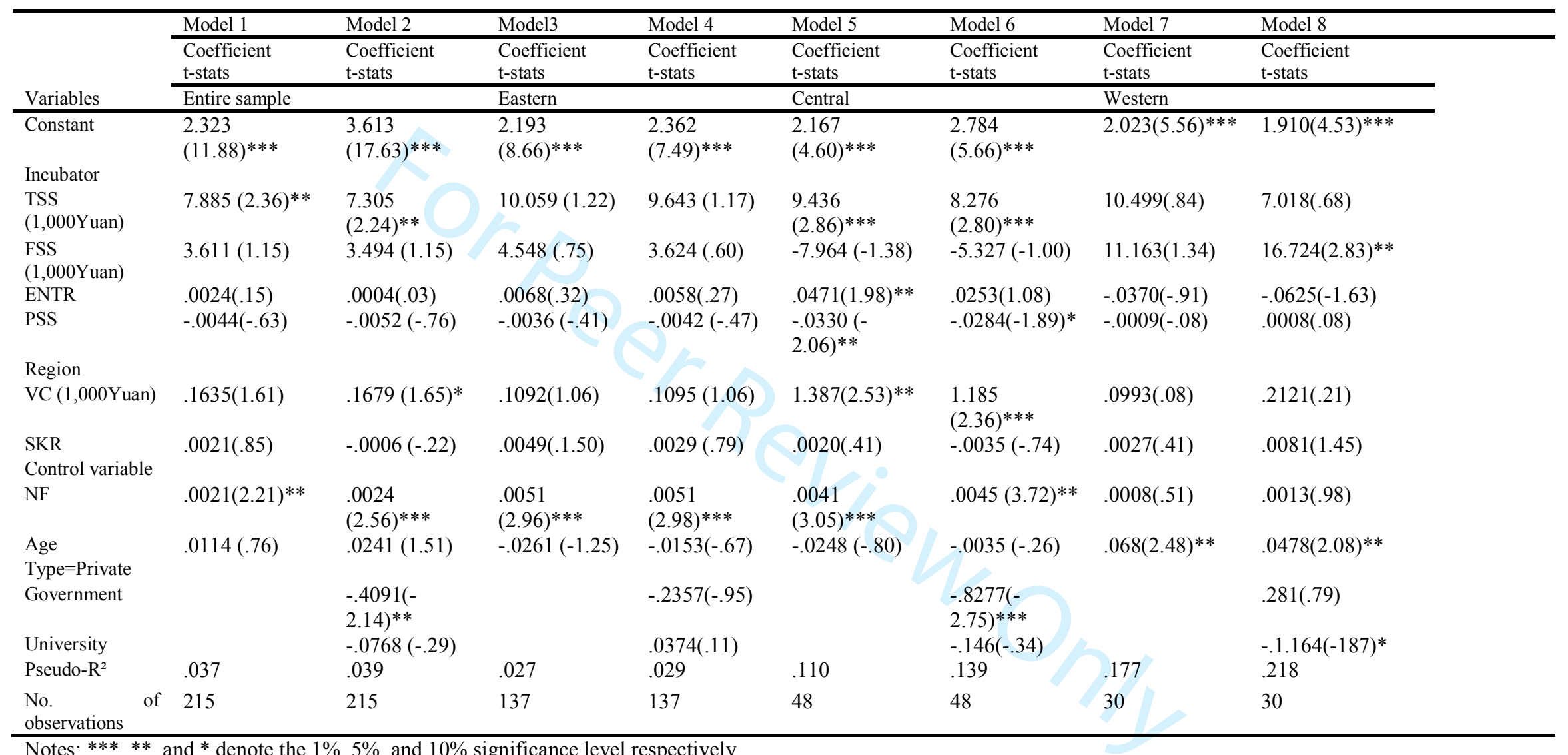


Table 7c Regression analyses of effects of regional and incubators' characteristics on National awards (Ps)

\begin{tabular}{|c|c|c|c|c|c|c|c|c|}
\hline & Model 1 & Model 2 & Model3 & Model 4 & Model 5 & Model 6 & Model 7 & Model 8 \\
\hline & $\begin{array}{l}\text { Coefficient } \\
\text { t-stats }\end{array}$ & $\begin{array}{l}\text { Coefficient } \\
\text { t-stats }\end{array}$ & $\begin{array}{l}\text { Coefficient } \\
\text { t-stats }\end{array}$ & $\begin{array}{l}\text { Coefficient } \\
\text { t-stats }\end{array}$ & $\begin{array}{l}\text { Coefficient } \\
\text { t-stats }\end{array}$ & $\begin{array}{l}\text { Coefficient } \\
\text { t-stats }\end{array}$ & $\begin{array}{l}\text { Coefficient } \\
\text { t-stats }\end{array}$ & $\begin{array}{l}\text { Coefficient } \\
\text { t-stats }\end{array}$ \\
\hline Variables & Entire sample & & Eastern & & Central & & Western & \\
\hline Constant & $\begin{array}{l}.8956 \\
(3.16)^{* * *}\end{array}$ & $\begin{array}{l}.8848 \\
(2.53)^{* * *}\end{array}$ & $.347(1.16)$ & $-.714(-.65)$ & $.498(.66)$ & $1.455(2.04)^{* *}$ & $1.980(3.10)^{* * *}$ & $1.830(2.12)^{* *}$ \\
\hline Incubator & & & & & & & & \\
\hline $\begin{array}{l}\text { TSS } \\
\text { (1,000Yuan) }\end{array}$ & $4.281(.85)$ & $4.216(.82)$ & $2.099(.24)$ & $-.165(-.02)$ & $3.765(.54)$ & $-4.908(-.83)$ & $-33.988(-1.46)$ & $-35.612(-1.56)$ \\
\hline $\begin{array}{l}\text { FSS } \\
\text { (1,000Yuan) }\end{array}$ & $7.915(1.88)^{*}$ & $\begin{array}{l}7.252 \\
(1.88)^{*}\end{array}$ & $8.884(1.47)$ & $11.764(1.94)^{*}$ & $-4.489(-.48)$ & $-2.492(-.32)$ & $28.736(1.76)^{*}$ & $31.647(1.84)^{*}$ \\
\hline ENTR & $.0148(.66)$ & $.0154(.68)$ & $.0296(.1 .25)$ & $.0352(1.51)$ & $-.03751(-.96)$ & $\begin{array}{l}-.0942(- \\
2.33)^{* *}\end{array}$ & $.0769(.96)$ & $.0697(.81)$ \\
\hline PSS & $-.0091(-.95)$ & $-.0092(-.96)$ & $\begin{array}{l}-.0214 \\
2.07)^{* *}\end{array}$ & $\begin{array}{l}-.0201 \\
1.99)^{* *}\end{array}$ & $.0241(1.11)$ & $.0464(2.37)^{* *}$ & $.0114(.46)$ & $.011(.43)$ \\
\hline Region & & & & & & & & \\
\hline $\begin{array}{l}\text { VC } \\
\text { (1,000Yuan) }\end{array}$ & $-.0264(-.23)$ & $-.0264(-.22)$ & $.0145(.14)$ & $-.0141(-.14)$ & $1.112(1.22)$ & $1.137(1.52)$ & $2.209(1.08)$ & $2.187(1.09)$ \\
\hline SKR & $.0035(1.02)$ & $.0038(.98)$ & $.0081(2.24)^{* *}$ & $\begin{array}{l}.0114 \\
(.2 .89)^{* * *}\end{array}$ & $.0166(.1 .99)^{* *}$ & $.0091(1.26)$ & $\begin{array}{l}-.0248(- \\
2.03)^{* * *}\end{array}$ & $-.0216(-1.64)$ \\
\hline Control variable & & & & & & & & \\
\hline $\mathrm{NF}$ & $.0041(3.40)^{* * *}$ & $\begin{array}{l}.0040 \\
(3.38)^{* * *}\end{array}$ & $\begin{array}{l}.0082 \\
(4.50)^{* * *}\end{array}$ & $\begin{array}{l}.0084 \\
(4.69) * * *\end{array}$ & $.0024(1.12)$ & $.0022(1.28)$ & $.0002(.06)$ & $.0004(.13)$ \\
\hline $\begin{array}{l}\text { Age } \\
\text { Type }=\text { Private }\end{array}$ & $.0035(.19)$ & $.0028(.13)$ & $-.0202(-.86)$ & $-.0376(-1.54)$ & $-.0212(-.49)$ & $.0350(.84)$ & $-.0139(-.27)$ & $-.0216(-.44)$ \\
\hline Government & & $.0186(.07)$ & & $.6661(2.30)^{* *}$ & & $\begin{array}{l}-1.611(- \\
3.40)^{* * *}\end{array}$ & & $.237(.34)$ \\
\hline $\begin{array}{l}\text { University } \\
\text { Pseudo-R }{ }^{2}\end{array}$ & .0456 & $\begin{array}{l}-.0548(-.15) \\
.046\end{array}$ & .062 & $\begin{array}{l}.4228(1.18) \\
.0739\end{array}$ & .075 & $\begin{array}{l}-.8141(-1.24) \\
.128\end{array}$ & .096 & $\begin{array}{l}-.338(-.29) \\
.098\end{array}$ \\
\hline $\begin{array}{l}\text { No. of } \\
\text { observations }\end{array}$ & 215 & 215 & 137 & 137 & 48 & 48 & 30 & 30 \\
\hline
\end{tabular}

Notes: $* * *, * *$, and $*$ denote the $1 \%, 5 \%$, and $10 \%$ significance level respectively. 